\title{
LOCAL WISDOM AND VALUE OF CHARACTER IN LEVEL OF AJI KRAMA AT SASAK WEDDING TRADITION
}

\author{
Agusman, Imam Suyitno, Yuni Pratiwi* \\ Postgraduate Education Indonesian, Malang State University, Indonesia
}

\begin{tabular}{l} 
A R T I C L E \\
\hline Keyword: \\
Local Wisdom, \\
Value, \\
Aji Krama
\end{tabular}

\begin{abstract}
A B S T R A C T
The discourse of marriage tradition when viewed based on a theoretical point of view will result in a form of concepts, meanings, and functions. In this case, the discourse of the tradition in question is the discourse of the sorong serah aji krama tradition. The discourse of this tradition is found in the Lombok-Sasak area located in Jonggat Subdistrict, Central Lombok District, West Nusa Tenggara Province (NTB). The axes of aji krama contained in this area have levels ranging from the bottom of the so-called 33, 66, and 100 . In this case, the study is to find the value contained in the level aji krama is also explained to the community that in the level of aji krama is not only limited to discourse or celebration in a mere cultural symbol, but contains the value of philosophical life. In this case, the method used in collecting data is an interview with a prominent traditional figure who knows the ins and outs of the tradition of handling the aji krama well. Thus, the data in this study is verbal aspect in the form of interviews related to the level of aji krama contained in the area. Data analysis in this case uses Hermeneutic's Ricoeur's thinking framework that sees a text of three levels, namely semantic level, philosophical level, and level of existence. Based on the results of this study, thrust of aji krama as a tradition of marriage which also has aji aji krama level has a strong philosophical foundation. It can be seen from the level of aji 33 which shows an understanding of self, God, and all his power obtained through understanding the nature of Allah SWT. Aji 66 is a multilevel of understanding aji 33 approaching to the category of human being (rodiallah) and aji 100 is the highest category to the understanding of the nature of self and God and all forms of his power gained from a deep understanding of the 99 ulma asthma that leads to one form, that is Allah SWT. Thus, the understanding is a category of local wisdom that contains the value of character and is represented in the form of religious character.
\end{abstract}

\section{INTRODUCTIONS}

Aji krama is a form of marriage tradition found in Lombok area. In this case, the handing over of aji krama as a tradition of marriage is certainly applicable throughout the Lombok region. This marriage tradition can also be said as a form of representation of a number of noble values, the symbols of life used, to the meaning of language (discourse) it contains. The languages, symbols, and values that make up a culture (the tradition of aji krama) are the elements that make up the units of meaning as a whole. For example, in the handing-hand of the aji krama, there are levels of value based on the social strata, ie 100 for the Raden descendants, 66 for the descendants of purwangsa, and 33 as the values given to the coral reef (ordinary people).

Based on the example of the aji level above, certainly in this case, there are values underlying the birth of the aji level. The values are also necessarily formed from a number of components that form one unity. The intended component is a forming of the culture itself as Usman (2012: 89-90) says about the cultural component. Furthermore, the tradition of the Sasak wedding is not just a primitive celebration, but a celebration that implies the values of life and even reflects on how everyday life or life is supposed to be.

\footnotetext{
* Corresponding author.

E-mail addresses: Agusman1990@yahoo.com (Agusman)
}

ISSN : 2597-7385 (Online) - ISLLAC : Journal of Intensive Studies on Language, Literature, Art, and Culture is licensed under Creative Commons Attribution-ShareAlike 4.0 International License (http://creativecommons.org/licenses/BY/4.0/).

45 | ISLLAC : Journal of Intensive Studies on Language, Literature, Art, and Culture 
This is in accordance with Williams's statement of the totality of culture as quoted Beilharz (2005: 377). If viewed from the expert's point of view, then daily life, routines, encounters, until the existence of agents in conscious or unconscious action will lead to the formation of culture. This statement if traced will be in accordance with the opinion of Giddens (2010) which describes the agent and the reproduction of actions as the basis for the formation of the social structure of society.

Based on the above exposition, then, in this case, all the substances contained in the tradition of shifting aji krama should be dismantled and interpreted in depth. Thus, all aspects of meaning to the deepest value can be understood by the community. This is the problem as well as a goal, namely to reveal the meaning of the value contained. For example, related to the value of 100 for the radio offspring is why, what, how, to the purpose of giving the value 100 is.

Based on the above statement, it can be said that the substance sought in this study is related to meaning and value. The substance contained in the shift aji krama can be used as the basis or foundation for the community, especially the owner of the culture itself to behave and reproduce the social action of morality/character. Maryani (2011: 1) explains "in the exploration of the ages to achieve the welfare objectives as well as the greatness of a nation", Indonesia needs energy in the form of sense of identity, solidarity (sense of solidarity), sense of belonging, and the pride of the nation (sense of pride). The statement provides an explanation that identity, solidarity, mutual ownership, and national pride are elements that become the value or content of wisdom. This is the basis of life so that people have the character of the cultural values contained. In addition, Parker and Bicker (2005: 23) mention local wisdom as local knowledge includes 5 things, as follows.

"(1) a knowledge that associated with a place, and set of experience, and developed by the local people; (2) a knowledge acquired by mimicry, imitation and experimenting; (3) day-today practical knowledge gained from trial and error; (4) an empirical knowledge which is not theoretical; and (5) comprehensive and integrated knowledge in the realm of tradition and culture."

In addition, Rahyono (2005: 3) explains that "the word 'wise' or 'wisdom' refers to the dictionary with regard to two things, namely (1) character or personality and (2) intelligence." Masinambow's opinion (2000: 36-37) which explains the following.

"The adherents of the humanistic concept of culture restrict culture to the noble values and ideals of perfection that man has and will achieve. All human effort according to humanistic concepts must be directed to the acquisition of perfection that can leave everything that is inferior. It is this humanistic culture that shows the presence of wisdom in culture. "

Therefore, local or local genius wisdom refers to the content of human values possessed by a local tradition or culture to be manifested in all aspects of characteristic life. This can be matched by Frondizi's statement (2011: 1-2) which explains value as a way of looking at things. This statement provides an explanation that the value is the way of the view of an object or thing which value is a spirit attached to the object or something that can be used as a tool/media in the reproduction of all forms of social action. Basically, all the values contained in local wisdom are directed to the community as the owner and agent of the culture itself to develop character. Character development or character education is a fundamental aspect that is urgent in the rigors of modernization. In this case, referring to the opinion of Creasy (2008) explains that "... character education is a program that can be implemented in order to turn students into respectful, responsible, contributing members of society."

The expert opinion above, explains that the object in the development of the character value is the student. Students as agents of the educational constitution are the objects of learning and the development of character values. Nevertheless, starting from the explanation of the above experts, the first character of character education is the society itself. This is because the community is the origin and purpose of each learning process so that students not only include the formal sphere, but also the non-formal domain. Thus, as Dimension argues (2009: 23) which explains "character education must teach how to make those values embedded and integrated into the totality of mind-action and manifested in real life." This is also in accordance with the statement put forward by Suyitno (2017) which explains the culture exists in every activity of human life. In every community activity, cultural values are upheld and adhered to by individual members of society. Reflections on the cultural values of society arise in the way of thinking, feeling, and behaving every day.

Based on a number of exposure experts above, it can be understood that the value as a content as well as a form of representation of a number of cultures can be used as a foundation in developing the character of humanity. The character in this case, is not a character categorized in the form of a formal domain, but all aspects of the character of social life and culture. It is of interest to cultural studies to explore and extract the essence of valuable content that can be packaged in the form of materials or media in learning. In 
addition, this is a perspective of a culture that culture is not basically a series of events that are not based on the values of wisdom and even the spiritual value of life, but they are a representation of the collective views of people socially and culturally.

Culture in its form is a combination of verbal and novel aspects as a result of the thought or creation of human taste in the interaction with nature and also fellow creatures. Culture in its element which consists of verbal and nonverbal aspect can be said as cultural discourse. The opinion of contemporary angular discourse put forward by John (2015: 1) explains the discourse of three things, "(1) anything beyond the sentence, (2) the use of language, and (3) wider social practices that include non- linguistic and non-linguistic language. "Referring to the expert's opinion, the three things are at the core so that a thing can be said to be a discourse, ie the existence of meaning, the use of language, and the social action of nonverbal or nonlinguistic.

Thus, based on the description above can be explained that the shift aji krama as a culture can be categorized as a cultural discourse that consists of a number of verbal and nonverbal aspects. This verbal and nonverbal aspect is a unit of meaning that becomes the object of analysis to get its meaning and its nature philosophically either from the ontological, epistemological, and axiological aspects. However, to understand all these things in a study is always required a scalpel or the main theory used for interpretation. In this case, the theory used is Hermeneutic's Ricoeur.

Hermeneutics initiated by Ricoeur can be seen from the statement "I am beyond the antinomy and phenomenology". This means that the interpreter must be able to understand well through the omission between the meaning and the phenomenon that exists until the interpreter must be able to understand well all the visible phenomena and explain the being of the apparent phenomenon. Furthermore, Indraningsih (2011) explains that there are three steps in making understanding when viewed from Ricoeur's frame of mind, namely first, a simple phenomenology stage characterized by a process of understanding the symbol in totality; second, the hermeneutic circle is the process of interpretation; and three, the understanding of symbols or the philosophical meanings of the process and the results of interpretation. As explained by Mulyono, et al (2013: 250-253) explains that the process of grafting between methods with metaphysics, the theory to ontology, and hermeneutics to phenomenology there are three stages traversed, namely semantic level, reflection level, and level of existence.

Based on the exposure of some opinions on hermeneutics above, it is explained that Ricoeur initiated hermeneutics as a result of a graft of phenomenology. In the process of application, hermeneutics moves in three steps, namely first, semantic stage. This stage is the earliest stage as a place of understanding language as a sign that has a structure. This will include an understanding of the symbols as well as the metaphorical aspects of the language. Ricoeur (2014) explains that symbols are aspects of language that have a double meaning, while metaphors are in the aspect of semantic understanding of connotation levels.

The second stage, namely the level of reflection. This stage is a philosophical hermeneutic circle. Mulyono, et al (2014) describes at this level hermeneutics must be able to reach a higher stage as an action or process of philosophy. It will be achieved in a process of turning back between understanding the text and self-understanding. It is similar to the dialectic or melting of Gadamer's cakrwala (Check Gadamer, 2010). The purpose of this level of reflection is to find self-understanding through the understanding of others. It is also a process of distance and feasibility.

The third stage, namely the level of existence. This stage is the most complex stage of ontology, which exposes the nature of the process and the understanding itself. In this case, it will also be faced with a process of deep understanding to know the nature of the geist as revealed by Ast (Check Palmer, 2016: 87). It is at this stage that understanding can be drawn to a more sacred aspect, the Phenomenology of Religion. This is also in accordance with Rumi's (2017) statement which explains that a language is merely a tool and the goal is to know the deep essence of the language process and what lies behind the phenomenon of language, the Divine aspect.

Thus, based on the exposure of a number of the above discussion can be explained that the handing over of aji krama as a culture has verbal and nonverbal aspects. This aspect needs to be explored and interpreted to know the meaning or content of its value which in this case is the purpose of this research. The results are values that can be loaded or developed into materials or media in developing the character either on a formal or nonformal scale.

\section{METHOD}

The data collection procedure in this study is faced directly to the natural context. That is, data collection is done by means of direct interaction. Thus, the data collection of this study was conducted through interviews with traditional leaders to reveal information from the aji krama level. 
This interview technique is conducted to obtain information about Sasak wedding tradition from a traditional figure (pembayun). This interview consists of two parts, first, an interview to get information in the form of a narrative aspect of the tradition that includes the origins of the tradition, the procedure of implementation, function/purpose, category, and its components (language, values, beliefs, social actions). Meanwhile, the second interview was conducted as an act of reflection as well as the validation of the findings (after an overall data analysis). This interview is unstructured, meaning that some questions are not structured (pre-defined), but more open. It aims to broaden the scope of the discourse of the tradition of marriage.

In addition, the criteria for selection of resource persons are not of a liking but selective nature. In this case, a number of aspects considered in the determination of resource persons are as follows.

a) A traditional leader, who has a role in handling a number of issues related to the implementation of culture or tradition.

b) Broadly speaking, the character has extensive knowledge and experience of adat system especially related to the discourse of Sasak wedding tradition from the perspective of diachronic and synchronic.

From the aspect criteria described above, it is helpful invalid data collection related to the discourse of Sasak wedding tradition.

The data is essentially the object of research. The data, in this case, will be related to the origin of the data is obtained. That is, the data is largely determined by the context's characteristics. This is in accordance with the opinion of Sudaryanto (1993: 3) which explains the nature of the data and its context. The level of Aji Krama is obtained from interviews of customary figures found in Bonjeruk Village area, Jonggat Subdistrict, Central Lombok NTB Regency. This area is chosen to be the location as well as the source of data because the area is a customary celebration is still thick and has a very close relationship with the kingdom of Pujut. All of these are the origin of data or data sources. This is in accordance with the opinion Siswantoro (2005: 63-64) which explains the nature of data sources in research.

Data analysis is the final step done after all data collected from three sources of data, namely interview techniques. Thus, the stage of data analysis, in this case, includes the presentation, namely the process of reading, identification, selection, and classification, and categorization in accordance with the focus of the problem; the phase of data analysis and last is inference or inference.

\section{FINDINGS AND DISCUSSIONS}

As the result of the interview (Thursday, 04 January 2018) with the indigenous leaders in the Bonjeruk area, Jonggat Subdistrict, Central Lombok District, NTB) is described as follows.

\section{Sorong Serah Aji Krama}

Aji krama is a marriage ceremony to perform the submission as well as acceptance of aji (value) krama (ordinance, marriage) of both couples through a messenger called the pembayun mentoring and pembayun preamp. The handing out of the aji krama was conducted between 14.00-16.00 WITA conducted by the pusher led by the pembayun which will be accepted by the winnowing pembayun as the envoy of the family of the bride.

Sorong serah aji krama is held when there are married sons. This is a customary marriage settlement or commonly referred to as a customary assembly. Aji can be interpreted as value and krama means the ordinance of marriage, so aji krama is defined as the value of a marriage. In addition, there is also a philosophy that is aji means to aji diriq (study, self-understanding) and krama means the ordinance, so it can also mean the process of self-understanding of the ordinance of life.

Based on the results of the above interviews, it can be explained that the handing over of aji krama as a tradition of the Sasak wedding is a ceremony performed when there is a couple of married youth. In this case, aji can be interpreted as value and krama means ordinance of marriage, so aji krama is defined as the value of a marriage. In addition, aji can be interpreted as a process of self-examination (self-understanding) based on the ordinance (krama) of the life. Thus, the result of self-understanding (self-understanding) based on the ordinance (krama) of the life is poured as a value of marriage as a foundation for building a household.

Based on the results of the above description, it can be explained that aji krama in history is a process of self-understanding as a form of God's creation as well as a ritual in the implementation of marriage which is indirectly the act of witnessing the value carried by each bride (bride). In addition, the handing over of aji krama philosophically can be interpreted as a process of assessment of the value of one's marriage as a result of self-understanding in the ordinance of living. That value is manifested as the spiritual foundation of the bride's two lives (Fitrahayunitisna \& Zulvarina, 2017). 
Meanwhile, the existence of aji krama in the second sense as a process of self-examination is a trace of knowledge to achieve the essence of the self as part of higher knowledge, that is absolute knowledge (God / divine truth). Aspects of this knowledge can be said as a form of local wisdom. In this case, the process of self-starting from the spiritual foundation of life is the essence of knowledge as the initial foundation which then manifested in the form of the land and shaped the structure of a complete human body to perform the Shari'a of religion Islam. This is a manifestation of the character of the former Sasak people who always self-perceived his being as God's creature. Thus, in this case, the form of character values contained in aji krama is curiosity and religious in accordance with the statement Wibowo (2012: 43-44).

\section{The level of Aji Krama}

In this case, the aji krama to be submitted in the pilot ceremony of aji krama has a level. This is a reflection of the social structure of society. The levels of aji krama can be seen in the following discussion.

\section{a. Aji Krama 33}

Aji krama 33 is the level of aji (value) of society below or said as a standard value. This applies to ordinary people. The following interview data of aji krama 33.

This aji is given to ordinary people (Jajar Karang). This aji is below or in other words aji which is at the standard value. In general, the public is in this aji position. In practice, Aji 33 is given the details, which nampak lemah 7, olen 26, tegep 33.

Aji 33 is the level given to the Jajar Karang community. This community can be regarded as the lower community level. Details of aji krama 33 consisting of nampak lemah and olen. Nampak lemah 7 refers to the value of the ability of a husband given to the wife and olen 26 is a symbol of the ability of the husband to provide the birth (clothes) to the wife. Aji 33 philosophically can be explained as the level of selfunderstanding It appears in the details of the meaning of untuh, which is obtained from 20 mandatory properties of Allah SWT and 13 means understanding of 13 pillars of prayer. It is this whole understanding which gives the explanation that in the detail of nampak lemah 7 which means the time of the creation of the universe, all the obligatory attributes of Allah are collected and they are represented in 13 rukun prayer and the 13 pillars of rukun prayer are manifested in action so that they are formed. Meanwhile, the interceptor (speech breaker) at this level means the witness to the assessment as well as the witness that the new self-understanding up to stage 33. Thus, the understanding is also balanced by doing good to the fellow human beings in this case giving reward (charity) to the head of government because it has been keeping the future wife during his life and bekao tindoq symbolized a keris that transformed into keris-aq

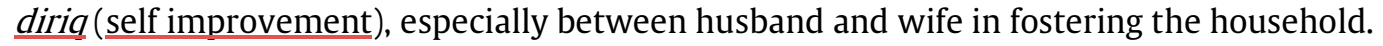

In addition, this aji 33 can also be understood as the level of understanding of all the attributes of God in charge over the whole of nature. It is apparent to the understanding that the 20 compulsory properties of Allah SWT fill 7 periods referring to 7 days. Thus, the compulsory nature of Allah Almighty controls all times so that it is represented in acts of service to Him through the understanding of the 13 pillars of rukun prayer and the 13 pillars of rukun prayer are put into action. This shows that in the level of aji 33 there is a deep understanding of the nature of Allah SWT which controls all time and indirectly form an explanation that Allah SWT is the highest substance aimed by all the properties, meanings, and forms in all beings of the universe and all.

Based on the above description, it can be concluded that aji krama 33, on the one hand, refers to the social level of a person and on the philosophical side refers to the level of self-understanding, god, and all his power. An understanding of the self that refers to God's power as the driving force of life and understanding of the compulsory nature of Allah SWT is a form of local wisdom. Thus, this local wisdom is used as a noble value as well as the basis of the character of society which is shown through the value of a religious character so that all forms of representation of social action is always based on the trust aspect to God as the ruler.

\section{b. Aji Krama 66}

In addition to the aji krama mentioned above, there is also aji krama which is at level 66. Aji (value) is given to people who still have offspring of nobility. In this case, this aji can be seen in a noble title called Baiq (female) and Bape (male). Here is the exposure of interview data aji krama 66.

Aji krama 66 is given to upper middle class (Purwangsa who has Baiq (female) and Bape (male)). The details include nampak lemah 20, olen 46, tegep 66, pemuput pembaos limang tali, penjaruman limang tali, makebo turu, mesalin dede. 
Aji 66 is a significant increase or multilevel value of 33, that is twice of the value of 33 is to be 66 . In detail, nampak lemah 20 refers to the value of the ability of the husband in giving life to the wife denoted by ancient money. Olen 46 refers to the value of the ability that must be given to the wife in the form of primary needs (clothing) which is symbolized by a number of fabrics. Meanwhile, the pemuput pembaos refers to the trial breaker during the execution of aji krama symbolized by the termination of the ancient money bond. Matchmaking is a term used to provide an explanation that two bridal families have family ties and there is an ancient amount of money that will be made as a reward to the head of the women's government and will be made a ransom if there are errors during the aji krama process. Meanwhile, kebo turu is a term that refers to the attitudes of the submissive wife and the husband's attitude responsible for giving the address to the wife symbolized by keris and mesalin dede is a symbol used to show the attitude of respect of the husband to the mother-in-law because as the mother of his wife who has provided parenting.

Aji 66 philosophically can be interpreted as a leap in value as a result of self-understanding and God. This can be seen from the nampak lemah detail of 20 which means that the spiritual footing of the man has increased to the understanding of the nature which is obligatory for Allah (SWT) and olen 26 is his possession as the realm for the Islamic Shari'a that is prayer as a representation of the understanding of the value of the 20 values. In this case, it is sufficient the husband's foundation in fostering the household that is the understanding that 20 plus the Shari'a 26 so tegep (enough) to 66. In addition, the shooter pemuput pembaos $5 \times 200$ and matchmaking $2 \times 500$ if multiplied to 10,000 , understood philosophically is 10 which means in human life there are always 10 angels as a witness of human actions. It is also constantly being improved as there is a term called makebo turu as the domain of self-improvement for the better and rewards the mother-in-law as a place of the blessing of God after the original mother called the mesalin dede.

This level of existence, aji 66 can be explained that a person has been able to increase selfunderstanding from level 33 to 66. This appears in the full understanding of this aji, that is 40 plus 26 to become 66. Number 40 refers to the understanding of the mandatory nature and 20 properties are not obligatory to Allah SWT and 26 is a form of execution of 13 pillars of rukun prayer which is understood and performed in action. In addition, there is also an understanding of doing good to the whole universe which is shown by giving the responsibility of salvation to a wife called kebo turu and paying homage to the mother-in-law for being the mother of his wife. They are all forms of understanding of self, God, and all his powers categorized as local wisdom. The value contained is what can be used as a foundation for developing the character of a better life. In addition, as described in the data above, it can be explained that the person at this stage is the one who still has the poetry of raden. This raden in the emic community is rodiallah, that is the person who has dridhoi God and deserve to be a model of noble life. Thus, this aji is the level of one's life that shows the understanding, attitudes, and actions that lead to the person who has been blessed by God. Thus, this level provides an in-depth understanding of the way of life as a form of God's power in all aspects of life. The formation of a noble or characteristic life is a manifestation of the noble values of the culture. This is in accordance with the statement Wibowo (2012) which describes the value of character and it's manifesting in life.

\section{Aji Krama 100}

The highest aji krama used in the area where the study is aji krama 100. This level is the top level. $A j i$ is destined to the noble who titled Raden or Lalu. Aji (value) is the level that can be categorized as the highest value of humanity. Here's the exposure of the interview data aji krama 100.

The level of aji krama 100 is given to Datu / Raden (the noble aristocracy) who is capable of being a role model and having the ability in all areas of life or a Great and Wise King. Details of this aji are nampak lemah 40, olen 60 , tegep 100 , pemuput pembaos 10 , penjaruman 10 , kebo turu, mesalin dede. However, in practice, it is not always specified as mentioned above. This means that this aji 100 is known to everything. People who are in this aji can be called hawasul hawas. In addition, it can be said also that, this aji 100 is the person who knows the secret of God.

Aji krama 100 can be interpreted as the highest value of aji krama Sasak (especially in the research area). In detail, it nampak lemah 40 symbolized by money perforated (for aji 100 there is always gold) is the value of a man. Olen which amounts to 60 symbolized by the perils (cloth) is the material value of the ability to provide the primary needs to the wife so that it appears weak and olen becomes a sufficiency for a man in building a life termed tegep (enough). In addition, there is also a symbol of the ability of the husband to give salvation to a wife called kebo turu, do good to the mother-in-law called mesalin dede, and give awards to the head of the female government called the matchmaking. 
Aji 100 can also be interpreted as a person's ability to understand the self and the existence of God. In addition, this aji 100 is also said to be a person who has become one with God and knows all the essentials. It is characterized by the obligatory nature of the 20 and the other 20 is not obligatory for Allah SWT manifestly manifested in olen 60 which is the beginning of human formation until he is able to carry out the 13 pillars of rukun prayer and all other Shari'a. Thus, as the knowledge continues to grow from the bottom (container) to the highest level 100 then the understanding will transform in the understanding of Asma ul Husna Allah SWT which all things and attributes always refer to Asma Allah. Thus, if all these things have been accomplished then nothing else becomes the last stop is the one God so that $99+1$ becomes 100 which is called tegep (enough).

Aji 100, on the one hand, can be the essence of understanding of all the power of God that can be understood through the existence of one's self. In addition, the understanding of the 99 Asma ul Husna Allah SWT is an activity to understand that all the reality of life always refers to this 99 Asma from the invisible to the visible so that in the end there is no power other than Him, that is Allah SWT so in this stage the meaning of the Islamic Tauhid sentence that there is no other than Allah as the ruler of this universe. This kind of understanding is extracted through the smallest element of the formation of the human being as an existence of God's creature until it moves to a greater / higher stage. All things or beings always keep the knowledge of God and this is what can be passed by a person gave aji 100. In accordance with the results of the interview, the person who reached aji 100 is called the rahadian which is interpreted as this level RODIALLAH, the person who has been blessed by Allah SWT or in other words the person who has been one with God (Ma'rifat level). Therefore, the content of the understanding of self, God, and all His power is a form of local wisdom. A form of representation of local wisdom that appears in the attitude of belief in God and all His powers is what shows a religious attitude or character. The attitude of mutual respect is also apparent in respect for the mother-in-law and the female head of government as well as the responsibility shown in giving a decent living salvation to the wife.

Based on the explanation above, it can be explained that the sorong serah aji krama in the research area has a level ranging from 33,66 , and 100. In this case, the aji krama as discussed above is the result of the value obtained from the process of self-understanding diriq), that is, aji krama which is described as a self-examination of krama (ordinance) which also produces the value witnessed in the adat session. In addition, the aji krama sessions are also on one side not only directed to the couple's bride but also become a ritual to provide a spiritual foundation for the life embryo to be born through the legal marriage process. However, this is very different from the present view which is more to see the culture of the material aspect simply does not go into the deep aspects to discover the nature of a better understanding.

Thus, a number of values in the form of religious, responsibility, and mutual respect are the values of characters that can be said to be the content of the value of the aji krama level. The content of character values can take the form of knowledge, skills, or a form of symbolization that can be said as a form of local wisdom community. The explanation of the level of aji krama, namely the value of aji 33 to 100 is a process of self-understanding (self-testing) to the understanding of the existence of the self as a form of God's power as a content in the tradition of shifting the aji krama. This value is called the substance of a tradition in accordance with the statement of Frondizi (2011: 1-2). The values contained in the tradition in the form of self-understanding for example in the discussion of aji 17 to aji 100 is the content of local wisdom as the opinion of Rahyono (2005) which explains about local wisdom and Masinambow (2000: 36-37).

A number of values that contain local wisdom, in this case, can certainly be used as a basis for developing the character of both the formal and non-formal scale. For example, the characters contained in bekao tindoq symbolized by keris which means kerisaq diriq (self-improvement) then life will run in harmony. From a number of character values that exist in the discussion of the aji levels above ranging from 17 to 100 that can be used as a medium in developing character education in accordance with the statement Creasy (2005) and Dimension (2009: 23). In fact, all the values contained in the culture can be established in the life as well as reflected in everyday life as affirmed by Suyitno (2017) about the culture that resides in every life activity that has value to be enforced together in life. In this case, the value of the character found is to include religious, dervish, hard work, curiosity, and social concern, or in other words, there is social and cultural social intelligence.

Thus, the level of aji krama contained in the discourse of Sasak wedding tradition has the substance of various values and meanings. This explains that tradition as a cultural discourse is necessarily based on significance and contains a number of symbols, languages, and social actions as described by Usman (2012: 89-90) on the cultural component and John (2015: 1) explaining the content of discourse. Therefore, the level of aji krama as a tradition of marriage is not a celebration that has no value but is the whole view of society because it contains various values that can be used as a foundation for a more harmonious life. This is in accordance with the opinion of Beilharz (2005: 377), Giddens (2010), and Maryani (2011: 1). 


\section{CONCLUSIONS}

Based on the above discussion, it can be concluded that the level of aji krama ranging from 33, 66, and 100 is the level of understanding obtained from the process of self-examination. Thus, aji krama can be regarded as a process of self-perceiving through krama (ordinance of life). Aji 33 is the whole level of comprehension which shows the comprehension of the mandatory nature plus the 13 pillars obtained from the unification of the understanding. Aji 66 is the stage of raising self-understanding and existence as God's creature that can be said near the level of rodiallah. Meanwhile, the aji 100 is the highest level called the level of disclosure of all understanding of God and all his powers. It is seen in the estuary of one form, that is Allah SWT which one as the core of the 9 names of Allah SWT that covers all the reality of life. Thus, a person who is in this level is called a rahadian which is interpreted as RODIALLAH, a person who has been blessed by Allah SWT or in other words a person who has become one with God (Ma'rifat level).

Knowledge or deference that refers to the understanding of the nature of the self, God, and all His power and understanding of the foundation of building a household is a form of local wisdom contained in the level aji krama them. The local wisdom contained a number of values as seen in the above description, the religious demonstrated by belief in God through all attributes and names possessed by the content of the character's value. In addition, the character value of responsibility appears in the obligation of the husband in providing all the needs of both the birth and the mind to the wife and there is also the value of mutual respect/mutual respect as evident in the remuneration to the mother-in-law and to the head of the government of the women. Thus, the knowledge that includes knowledge of identity, knowledge about the representation of all attributes and asthmaul husna Allah SWT, knowledge of the ordinance of life (especially in marriage) and generally live in the social and cultural realm is local wisdom. All categories of local knowledge (local genius) in this case are manifested in the form of religious human character, have socio-cultural intelligence in the aspects of responsibility, self-reliance, and social care. All these things are reflected in the content of aji krama as described in the above discussions section. Therefore, the aji level must be understood at the highest level in order to gain true knowledge of the secrets of the self as a manifestation of the existence of God's power to gain knowledge as a foundation in developing the character to live in a social and cultural frame.

\section{REFERENCES}

Alan, B. et al. (2005). Indigenious Environtment Knowledge and it's Transformations. Howard Academi Publisher: Singapore.

Beilharz, P. (2005). Teori-teori Sosial: Observasi Kritis terhadap Para Filosof Terkemuka. Terjemahan: Sigit Jatmiko. Yogyakarta: Pustaka Pelajar.

Creasy. (2008). What is Character Education?. Journal of Education Policy, Vol. 3, No. 12, Hal:172-180.

Dimenson, S. (2009). Character is Key: How to Unlock the Best in Our Children and in Our Self. Ontario: John Wiley and Sons Canada.

Fitrahayunitisna, F., \& Zulvarina, P. (2017). The Efforts to Strengthen National Identity Through Ethical Value and Local Wisdom in Oral Literature. ISLLAC: Journal of Intensive Studies on Language, Literature, Art, and Culture, 1(2), 19-23.

Frondizi, R. (2011). Pengantar Filsafat Nilai. Terjemahan: Cuk Ananta Wijaya. Yogyakarta: Pustaka Pelajar.

Giddens, A. (2010). Teori Strukturasi: Dasar-dasar Pembentukan Struktur Sosial Masyarakat. Penerjemah: Maufur dan Daryatno. Yogyakarta: Pustaka Pelajar.

Gadamer, H-G. (2010). Kebenaran dan Metode (Judul Asli: Truth and Method) Terjemahan: Ahmad Sahidah. Yogyakarta: Pustaka Pelajar.

Indraningsih. (2011). Hermeneutika Paul Ricoeur dan Penerapannya pada Pemaknaan Simbol dalam Roman "Rafilus" Karya Budi Darma. Jurnal Filsafat. Vol. 21. No.2. Online (https://jurnal.ugm.ac.id/article/view/pdf). Diakses tanggal 22 Desember 2017.

Little J. And Stephen, W. (1996). Theories of Human Communication. Fifth Edition. New York: Wadsworth Publishing Company.

Maryani, E. (2011). Kearifan Lokal sebagai Sumber Pembelajaran IPS dan Keunggulan Karakter Bangsa, Makalah Konvensi Pendidikan Nasional IPS. Bandung.

Masinambow, E. K. M. (2000). Hukum dan Kemajemukan Budaya. Jakarta: Yayasan Obor Indonesia. 
Palmer, R .E. (2016). Hermeneutika: Teori Baru Mengenai Interpretasi. Penerjemah: Musnur Hery dan Damanhuri Muhammed.Yogyakarta: Pustaka Pelajar.

Mulyono, E. dkk. (2013). Belajar Hermeneutika: Dari Konfigurasi Filosofis menuju Praksis Islamic Studies. Banguntapan Yogyakarta: IRCiSoD.

Rahyono, F.X. (2014). Kearifan Budaya dalam Kata. Jakarta: Widyatama Widya Sastra.

Rumi, J. (2017). Fihi Ma Fihi: 71 Ceramah Rumi untuk Pendidikan Ruhani. Jakarta Selatan: Zaman.

Siswantoro. (2005). Metode Peneltian Sastra: Analisis Psikologis. Surakarta: Muhammadiyah University Press.

Sudaryanto. (1993). Metode dan Aneka Teknik Ananlisis Bahasa: Pengantar Penelitian Wahana Kebudayaan Secara Linguistik. Seri ILDEP. Yogyakarta: Duta Wacana Press.

Suyitno, I. (2017). Development of Cultural Literacy to Build Students Character Through Learning. Journal of Inovative Studies on Character and Education.Vol. 1, Year 2017. (Online) , (http://iscjournal.com/index.php/isce), diakses tanggal 27 November 2017.

Usman, S. (2012). Sosiologi: Sejarah, Teori, dan Metodologi. Yogyakarta: Pustaka Pelajar.

Wibowo, A. (2012) . Pendidikan Karakter: Strategi Membangun Bangsa Berperadaban. Yogyakarta: Pustaka Pelajar.

53 | ISLLAC : Journal of Intensive Studies on Language, Literature, Art, and Culture 